\title{
CONDITIONS AND PROSPECTS OF IMPROVEMENT OF NON- AGRICULTURAL LAND EVALUATION IN UKRAINE AS CONSTITUENT OF THE STATE LAND CADASTRE
}

\author{
Susak Tetiana \\ Lviv National Agrarian University, Ukraine
}

\begin{abstract}
.
The article describes peculiarities of formation of the estimated constituent in the structure of the state land cadastre in Ukraine. The author gives analysis of the current Ukrainian practice of consideration of the intended use of a land plot while making normative monetary evaluation of non-agricultural land plots within and outside settlements. The conducted analysis of the methodology of normative monetary evaluation of the land of settlements and non-agricultural land outside the settlements confirms that in the process of evaluation, each of the methodologies considers the intended use of land plots in a different way, causing different value correlation between the lands of different categories and kinds of intended use. Differentiation of the estimated indices of the methodology of normative monetary evaluation of non-agricultural lands within and outside settlements absolutely disagree with one another. The article supplies conclusions on the necessity to transfer to a consistent approach of such differentiation without reference to the land plot location within or outside the settlements.

Basing on the analysis of statistical information on the sale of state- and communally-owned lands, the author defines the coefficients of correlation between the sale price of state- and communally-owned lands in 2017-2018 in Ukraine in terms of the kinds of intended use and the figures of the indices of differentiation of normative monetary evaluation of non-agricultural lands within and outside settlements depending on the intended use of the land plot. The author proposes changes to the approaches to differentiation of the indices of evaluation of the lands of different intended use on the base of market prices. The work also outlines the main problems and possible directions of transition to a large-scale evaluation of lands in Ukraine.
\end{abstract}

Key words: land cadastre, evaluation, land plot, non-agricultural land.

\section{Introduction.}

Nowadays, Ukraine experiences active establishment of the system of the state land cadastre. Creating the required regulatory and methodic base for its successful performance as a geo-information system, Ukraine is oriented on the key requirements to cadastre systems, which have been established in Europe and declared by the appropriate directives of the European Union and the EU organizations, which are engaged in the field of geodesy and land cadastre. The land cadastre serves as a base for economic, juridical and administrative decisions, planning and development of territories. Its geo-informational base is established on different sources and technologies, which supply collection, processing, systematization of information on land and give access to the information for a wide circle of users. For several years, Ukraine has already had the automatic system of identification of land plots, created a cartographic base of cadastre with application of aero photo and satellite images, materials of surface photography. The information on quantitative and qualitative characteristics of land plots and other objects of cadastre is getting updated, the list of cadastre information is expanded and its actuality is maintained, as well as legislation in the field of land cadastre is improved.

Implementation of the Directives of the European Union and the EU organizations in the field of land cadastre in Ukraine still has many peculiarities and specificity. Thus, the authors of the "Impact of legislative framework on the structure of the national cadastre systems" are right mentioning that the structure of a cadastre system greatly depends on the nation mentality (which also influences the legislative framework) (Лихогруд, Козіков, 2006).

The land cadastre in Ukraine still operates and is developed under the effect of those historical peculiarities, which were settled in the 60-70s of the last century in the Soviet Union. It is particularly notable concerning such constituents of the land cadastre as land evaluation. Land evaluation as a constituent of the land cadastre was approved by the Article 46 of the "Fundamentals of the land legislation of the Soviet Union and Soviet Republics", which were validated on July 1, 1969. At that time, the structure of the land cadastre included data of land use registration, accounting of quantity and quality of lands, soil assessment and economic evaluation of land. (Закон об утверждении Основ земельного законодательства ... 1969). The economic evaluation of land as a constituent of the land cadastre was approved by the Land Code of the Ukrainian SSR (Validated by the Law N 2874-VII 
(2874-07) of July 08, 1970, BBP, 1970, N 29, article 205). Data of the state land cadastre and particularly economic evaluation of that period were performed and mainly used for non-agricultural lands. However, it is worth noting that the need to make economic evaluation was theoretically argued and methodically initiated also for other categories of lands, distinguished at that historical stage (land of settlements (cities, towns, villages); lands of industrial, transportation, recreational purpose, reserved area and other non-agricultural use; lands of the state forest fund; lands of the state water fund).

After declaring the independence of Ukraine, to implement the land reform, which expected transition to the paid use of lands, the government initiated monetary evaluation of lands in the structure of the state land cadastre. The monetary evaluation was later divided into normative and expert ones. The first versions of the methodology of normative monetary evaluation of lands were approved by the Cabinet of Ministers of Ukraine in the middle of the 90s of the last century. Lack of experience of such works and the appropriate land market prevented applying the experience of the countries with a classical market economy in the process of their preparation. Thus, it is clear that the first version had numerous drawbacks and neglected many factors, influencing the price of real estate objects. Although land evaluation was used as a base for land payments, it caused public discontent and slowed down investments into Ukrainian economy. Considering those reasons, the methodologies have been revised many times. Referring to the legally approved land distribution into the categories, the methodologies of such evaluation were shaped for agricultural lands, lands of settlements, and non-agricultural lands except for the lands of settlements. Such division is still used. It has forced some contradictories of the evaluation procedures and methodologies, which finally caused disproportions of the obtained indices of the normative monetary evaluation, calculated by different methodologies.

Ukraine has recently introduced changes in the regulatory support and methodology of performance of the monetary evaluation of agricultural lands (Методика нормативної грошової оцінки земель сільськогосподарського призначення ... 2016) and settlements (Методика нормативної грошової оцінки земель населених пунктів ... 1995, Порядок нормативної грошової оцінки земель населених пунктів ... 2018). The last changes, which concerned non-agricultural lands outside settlements were introduced in 2013 (Методика нормативної грошової оцінки земель несільськогосподарського призначення (крім земель населених пунктів ... 2011. Порядок нормативної грошової оцінки земель несільськогосподарського призначення (крім земель населених пунктів ... 2013).

There are a lot of scholars in Ukraine, who are supposed to opine that there should be the transit for the European evaluation standards (TEGOVA, 2016), International evaluation standards (IVSC, 2020), Red Paper (RICS, 2014) and wider use of international experience by applying the respective mathematical apparatus in lands evaluation (Tom Kauko, 2008; Ellerman D. 1994). The automatic model of land plots evaluation, which are based on the methods and rules of unrestricted logics, are considered to be prospective for using (Holms at. al., 2017). (Zrobek, S, 2020). Such methods are based on the theory of unclear multiples and use linguistic measures, which enables to apply the biased expert knowledge about the points of the subject without their formalization, within the frame of traditional mathematical models, for decision-making process. However, the existing Ukrainian standards of evaluation adjustment to the international ones requires their adaptation to the socio-economic conditions and regulatory, and methodical base, which are valid in Ukraine. Thus, the mentioned change is impossible unless being properly considered.

The monetary evaluation of agricultural lands does not depend on whether it is within the settled area, and evaluation of non-agricultural land plots is performed by different methods and algorithms, using different basic indices and their differentiation. Different approaches and methods of evaluation cause that non-agricultural land plots, located within and outside settlements greatly differ with no consideration of the factors of location.

Considering the current economic situation in the country, implementation of the administrative reform, which also assumes redistribution of the budget income in favor of the local government, causes significant losses and social discontent. Because of those factors, there is a need to improve the methodology of differentiation of the indices of evaluation in terms of intended use of land plots.

The problems of land cadastre in Ukraine and land evaluation as its important constituent are studied in the works of many Ukrainian scientists. Among them, the works by Yu.F. Dekhtiarenko, (Дехтяренко Ю.Ф. et al. 2007), М.Н. Stupen (Ступень М.Г. et al., 2006) and many others. Concerning the topic of the present research, it is of particular interest to study the findings, which deal with the issue of relation of the results of normative monetary evaluation of the territory of settlements of different categories (Пелеха Ю.М, 2012) and methodic aspects of the normative monetary evaluation of non-agricultural 
lands (Мартин А.Г, 2013). Moreover, peculiarities of consideration of the intended use of land plots in the process of normative monetary evaluation of non-agricultural lands, particularly outside settlements, are poor studied.

The aim of the article is to analyze the existing methodologies of normative monetary evaluation of nonagricultural lands and develop proposals on improvement of the procedure of consideration of the functional use of land plots in the process of their evaluation.

\section{Discussion and results.}

According to the Ukrainian laws, normative monetary evaluation of non-agricultural land plots is regulated by two different regulatory acts. The methodology of normative monetary evaluation of the lands of settlements and the methodology of normative monetary evaluation of non-agricultural lands, except for the lands of settlements, and the appropriate procedures, which specify separate methodic aspects and the evaluation procedure, sufficiently differ in terms of consideration of the functional use of the land plot.

The normative monetary evaluation of the lands of settlements is calculated by capitalization of cost for development and arrangement of the territory, calculated per one square meter with consideration of the regional coefficient, which characterizes dependence of the rent income on the settlement position in the national, regional and local systems of production and settling, the zonal coefficient, which characterizes the city-planning worth of the territory within the settlements (economic-planning zone) and the local coefficient, which considers the land plot location within the economic-planning zone. The normative monetary evaluation of a separate land plot is calculated as a product of the obtained value and the area of the land plot, as well as the coefficient, which characterizes functional use of the land plot.

Table 1

Coefficients of functional use, which are used to calculate the indices of normative monetary evaluation of lands

\begin{tabular}{|l|c|c|c|c|}
\hline \multicolumn{1}{|c|}{ Section and title of the division of the intended use kinds } & \multirow{2}{*}{$\begin{array}{c}\text { Number of } \\
\text { subdivisions }\end{array}$} & \multicolumn{3}{|c|}{ Kf } \\
\cline { 3 - 5 } & average & min & max \\
\hline Section A Agricultural lands & 14 & 1.029 & 0.7 & 2.5 \\
\hline Section B Lands under residential and public buildings & 27 & 1.166 & 0.7 & 2.5 \\
\hline lands under residential building & 10 & 1.05 & 1 & 1.5 \\
\hline lands under public building & 17 & 1.282 & 0.7 & 2.5 \\
\hline $\begin{array}{l}\text { Section C Land of natural reserve and other environmental protection } \\
\text { purpose }\end{array}$ & 12 & 0.5 & 0.5 & 0.5 \\
\hline$\quad$ lands of the natural reserve fund & 11 & 0.5 & 0.5 & 0.5 \\
\hline lands of other environmental protection purpose & 1 & 0.5 & 0.5 & 0.5 \\
\hline Section D Lands of health purpose & 4 & 0.5 & 0.5 & 0.5 \\
\hline Section E Lands of recreational purpose & 5 & 0.5 & 0.5 & 0.5 \\
\hline Section G Lands of historic and cultural purpose & 4 & 0.5 & 0.5 & 0.5 \\
\hline Section H Forest fund lands & 3 & 0.833 & 1 & 1 \\
\hline Section I Water fund lands & 12 & 0.642 & 0.5 & 1.2 \\
\hline $\begin{array}{l}\text { Section J Lands of industrial, transportation, communications, energy, } \\
\text { defense and other purpose }\end{array}$ & 34 & 0.8222 & 0.5 & 1.2 \\
\hline lands of industrial purpose & 5 & 0.95 & 0.65 & 1.2 \\
\hline lands of transportation & 11 & 1.091 & 1 & 2.5 \\
\hline lands of communication & 5 & 0,92 & 0.5 & 1.2 \\
\hline lands of energy purpose & 3 & 0.65 & 0.65 & 0.65 \\
\hline lands of defense & 10 & 0,5 & 0.5 & 0.5 \\
\hline $\begin{array}{l}\text { Section K Undistributed lands, lands of the reserve fund and commong } \\
\text { use }\end{array}$ & 4 & 0.3 & 0.1 & 0.5 \\
\hline undistributed lands & 1 & 0.1 & 0.1 & 0.1 \\
\hline lands of the reserve fund & 1 & 0.1 & 0.1 & 0.1 \\
\hline lands of common use & 1 & 0.5 & 0.5 & 0.5 \\
\hline $\begin{array}{l}\text { for the goals of the section K and for protection and use of lands of } \\
\text { the natural reserve fund }\end{array}$ & 1 & 0.5 & 0.5 & 0.5 \\
\hline Total & 119 & & & \\
\hline
\end{tabular}

The coefficient, which characterizes functional use of the land plot (hereafter Kf), is determined basing on the Classification of kinds kinds of intended use of lands (Класифікації видів цільового 
призначення земель ... 2010). According to the classifier, there are ten distinguished sections, which correspond to the land categories, 19 divisions of the kinds of intended use, and 119 subdivisions of the kinds of intended use (Table 1).

To make comparison, the author of the work calculated the average figures of the coefficients for the sections and the range of variation from the minimal to the maximal value. The minimal value does not include the coefficient $\mathrm{Kf}=0.5$, which is determined for all groups of the kinds of land use (except for the land under public buildings) and for protection and use of the land of the natural reserve fund. Due to the great differentiation of the coefficient of functional use, its average values little variate from the maximal value $\mathrm{Kf}=1.166$ (from 0.7 to 2.5 ) of the land of residential and public buildings, to the minimal value for undistributed lands, lands of the reserve fund and common use - $\mathrm{Kf}=0.3$ (from 0.1- to 0.5).

For the lands of health purpose, lands of recreational purpose, lands of historic and cultural purpose, the value of the coefficient is the same for all subdivisions, i.e. $\mathrm{Kf}=0.5$ The law has set the coefficient $\mathrm{Kf}=0.5$ for the majority of subdivisions (Table 2) of the intended use of land, i.e. 54 (45.4\%), whereas for 29 (24.4\%) subdivisions, the coefficient is $\mathrm{Kf}=1.0$. The maximal value of the coefficient $\mathrm{Kf}=2.5$ is set for seven subdivision of the kinds of intended use. Although for one kind, particularly 03.17 For placing and exploitation of the establishments of servicing of the visitors of recreational objects, the coefficient is $\mathrm{Kf}=2.0$. The minimal value, i.e. 0.1 , is determined for undistributed lands and lands of the reserve fund.

Table 2

Distribution of the coefficients of functional use by the number of the kinds of intended use

\begin{tabular}{|c|c|c|}
\hline \multirow{2}{*}{ Value of the coefficient of functional use (Kf) } & \multicolumn{2}{|c|}{ Kinds of the intended use of lands } \\
\cline { 2 - 3 } & number & 1.68 \\
\hline 0.1 & 2 & 45.38 \\
\hline 0.5 & 54 & 4.20 \\
\hline 0.65 & 5 & 10.08 \\
\hline 0.7 & 12 & 24.37 \\
\hline 1 & 29 & 5.88 \\
\hline 1.2 & 7 & 1.68 \\
\hline 1.5 & 2 & 0.84 \\
\hline 2 & 1 & 5.88 \\
\hline 2.5 & 7 & 100.00 \\
\hline
\end{tabular}

According to the Methodology of normative monetary evaluation of non-agricultural lands (except for the lands of settlements), approved by the Cabinet of Ministers of Ukraine on November 23, 2011 № 1278 , the normative monetary evaluation of non-agricultural lands (except for the lands of settlements) $(\mathrm{P})$ is calculated by the formula:

$$
\mathrm{P}=\mathrm{S} \text { х D х Ск х Км х Кв х Кс х Ki, }
$$

where $\mathrm{S}$ - stands the area of a land plot:

$\mathrm{D}$ - stands for the rent income for the appropriate category of lands (in UAH per year);

Ск - stands for the term of capitalization (in years);

$\mathrm{K}_{\mathrm{M}}$ - stands for the coefficient, which considers the land location;

$\mathrm{K}_{\mathrm{B}}$ - stands for the coefficient, which considers the kind of the land plot use and is determined depending on the content of the lands according to the data of the State land cadastre;

Kc - stands for the coefficient, which considers the land plot belonging to the lands of environmental protection, health, recreational, historic and cultural purpose;

$\mathrm{Ki}$ - stands for the coefficient of indexation of normative monetary evaluation of lands.

Referring to the calculation formula, the differentiation is made by the value of the rent income, depending on the intended use of the land plot (Table 3). The lands of recreational purpose are taken as a basis for comparison. Under such conditions, for the lands of industrial purpose, the rent income is ten times higher than the one on the lands of recreational purpose, whereas the rent income on the forest fund lands is ten times less (considering different terms of capitalization, the figure is almost seven times). 
Standards of rent income for the corresponding category of lands

\begin{tabular}{|l|c|c|}
\hline \multicolumn{1}{|c|}{ Category of lands } & $\begin{array}{c}\text { Correlation } \\
\text { Rent income, } \\
\text { UAH/m² per } \\
\text { year }\end{array}$ & $\begin{array}{c}\text { coefficient referring } \\
\text { to the recreational } \\
\text { lands } \\
\text { (Ks) }\end{array}$ \\
\hline Lands of natural reserve and other environmental protection purpose & 0.1179 & 1.880 \\
\hline Lands of health purpose & 0.0752 & 1.199 \\
\hline Lands of recreational purpose & 0.0627 & 1.000 \\
\hline Lands of historic and cultural purpose & 0.1191 & 1.900 \\
\hline Forest fund lands & 0.0063 & 0.100 \\
\hline Water fund lands & 0.0211 & 0.337 \\
\hline $\begin{array}{l}\text { Lands of industrial, transportation, communication, energy, defense and } \\
\text { other purpose }\end{array}$ & 0.6637 & 10.585 \\
\hline
\end{tabular}

Table 4 presents information on the values of the coefficients of functional use, which are applied in the process of evaluation of the lands of settlements (Kf) and the corresponding correlation coefficients of the rent income of normative monetary evaluation of non-agricultural lands outside the settlements (Ks).

Table 4

Coefficients of functional use (Kf) and the correlation coefficients of the rent income of normative monetary evaluation of non-agricultural lands outside settlements (Ks)

\begin{tabular}{|c|c|c|c|c|}
\hline \multirow{2}{*}{ Section of the kinds of intended use } & \multicolumn{3}{|c|}{ Kf } & \multirow{2}{*}{$(\mathbf{K s})$} \\
\hline & average & $\min$ & $\max$ & \\
\hline $\begin{array}{l}\text { Section C Lands of natural reserve and other environmental protection } \\
\text { purpose }\end{array}$ & 0.5 & 0.5 & 0.5 & 1.880 \\
\hline Section D Lands of health purpose & 0.5 & 0.5 & 0.5 & 1.199 \\
\hline Section E Lands of recreational purpose & 0.5 & 0.5 & 0.5 & 1.000 \\
\hline Section G Lands of historic and cultural purpose & 0.5 & 0.5 & 0.5 & 1.900 \\
\hline Section H Forest fund lands & 0.833 & 1 & 1 & 0.100 \\
\hline Section I Water fund lands & 0.642 & 0.5 & 1.2 & 0.337 \\
\hline $\begin{array}{l}\text { Section J Lands of industrial, transportation, communication, energy, } \\
\text { defense and other purpose }\end{array}$ & 0.8222 & 0.5 & 2.5 & 10.585 \\
\hline
\end{tabular}

The analysis of the Table 4 confirms that the current approaches to normative monetary evaluation of non-agricultural lands force a significant disproportion of estimated indices of different categories of lands. Table 5 supplies calculation of the coefficients of discrepancy of consideration of the functional use of land plots in the methodology of evaluation of the lands of settlements, the coefficient (Kf) and correlation of the rent income of normative monetary evaluation of non-agricultural lands outside the settlements (Ks). The obtained coefficients demonstrate that the greatest distortion happens in case of the forest fund lands, lands of industrial, transportation, communication, energy, defense and other purpose. 
Table 5

Coefficient of discrepancy of consideration of the functional use of land plots in the methodology of evaluation of the lands of settlements

\begin{tabular}{|c|c|c|c|c|c|c|c|}
\hline \multirow{3}{*}{$\begin{array}{l}\text { Section and title of the division of } \\
\text { the intended use kinds }\end{array}$} & \multirow{2}{*}{\multicolumn{2}{|c|}{ Kf }} & \multirow{3}{*}{$\begin{array}{l}\text { Adjusted value of } \\
\text { the coefficient Ks } \\
\text { (Section } E=0.5 \text { ) }\end{array}$} & \multicolumn{4}{|c|}{ Discrepancy coefficient } \\
\hline & & & & \multicolumn{2}{|c|}{ Ks to Kf } & \multicolumn{2}{|c|}{ Kf to Ks } \\
\hline & $\min$ & $\max$ & & $\min$ & $\max$ & $\min$ & $\max$ \\
\hline $\begin{array}{l}\text { Section C Lands of natural reserve } \\
\text { and other environmental protection } \\
\text { purpose }\end{array}$ & 0.5 & $0 ., 5$ & 0.94 & 0.532 & 0.532 & 1.880 & 1.880 \\
\hline Section D Lands of health purpose & 0.5 & 0.5 & 0.6 & 0.833 & 0.833 & 1.200 & 1.200 \\
\hline $\begin{array}{l}\text { Section E Lands of recreational } \\
\text { purpose }\end{array}$ & 0.5 & 0.5 & 0.5 & 1.000 & 1.000 & 1.000 & 1.000 \\
\hline $\begin{array}{l}\text { Section G Lands of historic and } \\
\text { cultural purpose }\end{array}$ & 0.5 & 0.5 & 0.95 & 0.526 & 0.526 & 1.900 & 1.900 \\
\hline Section H Forest fund lands & 1 & 1 & 0.05 & 20.000 & 20.000 & 0.050 & 0.050 \\
\hline Section I Water fund lands & 0.5 & 1.2 & 0.168 & 2.976 & 7.143 & 0.336 & 0.140 \\
\hline $\begin{array}{l}\text { Section J Lands of industrial, } \\
\text { transportation, communication, } \\
\text { energy, defense and other purpose }\end{array}$ & 0.5 & 2.5 & 5.293 & 0.094 & 0.472 & 10.586 & 2.117 \\
\hline
\end{tabular}

Nowadays, in Ukraine, after introduction of transparent mechanisms of sale of the state- and communally-owned lands, there is available information, delivered on the website of the State GeoCadastre, on the results of sale of the lands of different intended use. To assess on how the current mechanisms of consideration of the functional peculiarities of land use correlate with the results of sale of the lands of different intended use, the author of the work has conducted the analysis of relevant information on the sale of land plots and the rights of their lease.

Table 6

Price of the sold state- and communally-owned land plots in 2017-2018 in terms of their intended use

\begin{tabular}{|l|c|c|c|}
\hline \multirow{2}{*}{ Code of the intended use of the land plot } & \multicolumn{3}{|c|}{ Price for $\mathbf{1} \mathbf{~ m}^{\mathbf{~} \text { of the land plot }}$} \\
\cline { 2 - 4 } & average & minimal & maximal \\
\hline Agricultural lands & 36.16 & 18.80 & 100.65 \\
\hline Lands under residential building & 251.04 & 1.47 & 3743.48 \\
\hline Lands under public building & 179.07 & 1.90 & 6800.00 \\
\hline Lands of health purpose & 151.47 & 17.57 & 834.29 \\
\hline Lands of recreational purpose & 67.43 & 2.27 & 443.31 \\
\hline Water fund lands & 64.84 & 55.31 & 68.82 \\
\hline lands of industrial purpose & 75.66 & 6.06 & 5809.83 \\
\hline lands of transportation & 102.88 & 18.07 & 2977.12 \\
\hline lands of communication & 157.23 & 38.52 & 447.55 \\
\hline lands of energy purpose & 17.02 & 10.71 & 338.40 \\
\hline Undistributed lands & 73.58 & 71.47 & 171.11 \\
\hline
\end{tabular}

Calculated by the author using the data of the State GeoCadastre of Ukraine https://land.gov.ua/info/stan-formuvannia-rynku-zemel-v-ukraini

The article also provides consolidated data on the sale of state- and communally-owned lands in Ukraine in 2017-2018 depending on the intended use of the land plots (Table 6), as well as the price of the rights of the land plots lease (Table 7). 
Table 7

Price of sale of the rights of lease of the state- and communally-owned land plots in 2017-2018

\begin{tabular}{|c|c|c|c|}
\hline \multirow{2}{*}{ Intended use of the land plot } & \multicolumn{3}{|c|}{ price of lease of the land plot, UAH for $1 \mathbf{~ m}^{2}$ in year } \\
\hline & average & minimal & maximal \\
\hline Agricultural lands & 0.32 & 0.0036 & 933.4400 \\
\hline Lands under residential building & 7.97 & 0.1500 & 335.2700 \\
\hline Lands under public building & 22.71 & 0.3900 & 6100.1760 \\
\hline Lands of recreational purpose & 31.23 & 0.8716 & 148.6872 \\
\hline Water fund lands & 0.31 & 0.0376 & 112.5100 \\
\hline Lands of industrial purpose & 7.58 & 0.0376 & 746.9106 \\
\hline Lands of transportation & 15.23 & 1.7788 & 608.1100 \\
\hline Lands of communication & 52.59 & 52.5886 & 52.5886 \\
\hline Lands of energy purpose & 2.65 & 1.9520 & 6.5322 \\
\hline Lands of common use & 8.27 & 8.2700 & 8.2700 \\
\hline Total & 0.39 & 108.9359 & 8242.6754 \\
\hline
\end{tabular}

Calculated by the author using the data of the State GeoCadastre of Ukraine https://land.gov.ua/info/stan-formuvannia-rynku-zemel-v-ukraini/

Excluding agricultural lands out of the conducted analysis, the author of the research studies the correlation of the indices of normative monetary evaluation of lands with the results of sale of the stateand communally-owned lands, which are officially published on the website of the State GeoCadastre. Table 8 presents figures of the coefficients of correlation between the average value of the price of sale of state- and communally-owned land plots and rights of their lease in Ukraine in 2017-2018, the coefficient of the functional use Kf of the current procedure of normative monetary evaluation of settlements in terms of subdivisions of the kinds of intended use. It confirms no correlation dependence.

Table 8

Coefficient of correlation between the average value of the price of sale of state- and communallyowned land plots and the rights of their lease in 2017-2018

\begin{tabular}{|l|c|c|c|}
\hline \multirow{2}{*}{ Kind of transaction } & \multicolumn{3}{|c|}{ Correlation coefficient } \\
\cline { 2 - 4 } & Average & Minimal & Maximal \\
\hline sale of lands & 0.376 & 0.029 & 0.402 \\
\hline sale of the rights of lease & 0.443 & 0.114 & 0.394 \\
\hline
\end{tabular}

Table 9

Coefficient of correlation between the average value of the price of sale of state- and communallyowned land plots and the rights of their lease in 2017-2018

\begin{tabular}{|l|c|c|c|}
\hline \multirow{2}{*}{\multicolumn{1}{|c|}{ Kind of transaction }} & \multicolumn{3}{c|}{ Correlation coefficient } \\
\cline { 2 - 4 } & Average & Minimal & Maximal \\
\hline sale of lands $*$ & -0.026 & -0.213 & 0.971 \\
\hline sale of the rights of lease $* *$ & 0.195 & 0.999 & 0.996 \\
\hline
\end{tabular}

* Because of no agreements, the analysis is conducted referring to the data of sale of the lands of the water fund, recreational, health purpose, and lands of industrial, transportation, communication, energy, defense and other purpose.

** Because of no agreements on the sale of the rights of lease of the state- and communally-owned lands, the analysis is conducted referring to the data on sale of the water fund lands, lands of recreational purpose, and lands of industrial, transportation, communication, energy, defense and other purpose.

The great coefficient of correlation between the average value of the price of sale of the rights of lease of the state- and communally-owned land plots in 2017-2018 and the coefficient of correlation of the rent income of normative monetary evaluation of non-agricultural lands outside settlements (Ks) is forced by the fact that the normative monetary evaluation is the basis for determination of the price of the rights of the land plots lease. 


\section{Conclusions.}

The conducted analysis of the methodology of normative monetary evaluation of the lands of settlements and non-agricultural lands outside settlements provides the conclusion that in the process of evaluation, each of the methodologies considers the functional use of lands plots in a different way, resulting in different price correlations between the lands of different categories and kinds of intended use. The differentiation of the estimated indices of the methodology of normative monetary evaluation of nonagricultural lands within and outside settlements absolutely disagree with one another. To remedy the situation, it is necessary to transfer to a consistent approach to such differentiation without reference to the land plot location within or outside settlements.

In Ukraine, the current approaches to differentiation of the normative monetary evaluation for the purpose of consideration of the intended use of lands do not concern the pricing tendencies at the market that is confirmed by absence of correlation between the price of sale of the state- and communallyowned lands in 2017-2018 in Ukraine in terms of the kinds of intended use, and the values of the indices of differentiation of normative monetary evaluation of non-agricultural lands within the boundaries and outside settlements depending on the intended use of the land plot.

The author of the work considers that those drawbacks are caused by the fact that the above-mentioned coefficients or the standards of rent income, which serve as a basis for differentiation of the estimated indices of the land plots of different categories, are not scientifically argued. Since the normative monetary evaluation is a base for taxation, such imperfection of the mechanism can be partially substantiated by supplied privileges on tax payment.

In the work, it is proposed to change the approaches to differentiation of the indices of evaluation of the lands of different intended use and substantiate them basing on market data on the sale of lands of different intended use for a gradual transition to a large-scale evaluation of lands in Ukraine according to the international standards.

Simplification of the procedure of change of the intended use of land plots by the landowners also forces the need to develop a new version of the classifier of the kinds of intended use of land plots in Ukraine.

\section{References}

1. Ellerman D. (1994). Mathematics of Real Estate Appraisal. EDI of the World Bank, 1994.

2. HOLMS, J., ARHIPOVA, I. and TULBURE, I. (2017). Ecosystem Provisioning Services Automated Valuation Process Model for Sustainable Land Management. ICTE Conference : Riga Tech Univ, Riga, Latvia. 2017. p. 104 3. IVS (2020) International Valuation Standards. https://www.rics.org/globalassets/ricswebsite/media/upholding-professional-standards/sector-standards/valuation/international-valuation-standards-

rics2.pdf

4. RICS (2014) RICS Valuation - Professional Standards January 2014. http://hoadd.noordhoff.nl/sites/7605/_assets/7605d24.pdf

\begin{tabular}{llll}
\hline 5. TEGOVA & (2016) & European & Valuation
\end{tabular}
https://www.tegova.org/data/bin/a5738793c0c61b_EVS_2016.pdf

6. Tom Kauko, Maurizio d'Amato..(2008) Mass Appraisal Methods: An international perspective for property valuers, London: Wiley-Blackwell, 2008. 335p

7. Zrobek, S., Kovalyshyn, O., Renigier-Biłozor, M., Kovalyshyn, S., Kovalyshyn, O. Fuzzy logic method of valuation supporting sustainable development of the agricultural land market. Sustainable Development 2020, https://doi.org/10.1002/sd.2061

8. Держгеокадастр України (GeoCadastre of Ukraine). (https://land.gov.ua/info/stan-formuvannia-rynkuzemel-v-ukraini ) (In Ukrainian)

9. Дехтяренко Ю.Ф., Лихогруд М.Г., Манцевич Ю.М., Палеха Ю.М. (2007) Методичні основи грошової оцінки земель в Україні (Methodic fundamentals of monetary evaluation of lands in Ukraine), Профі, Київ, 624 c. (In Ukrainian)

10. Дехтяренко Ю.Ф., Манцевич Ю.М., Палеха Ю.М., Тарнопольский А.В. Вплив грошової оцінки на ринок земель у Києві: стан, проблеми та перспективи розвитку (Impact of monetary evaluation on the land market in Kyiv: conditions, problems and prospects of development) // Землеустрій і кадастр, № 1, 2008. С. 5968. (In Ukrainian)

11. Закон об утверждении Основ земельного законодательства Союза CCP и Союзных Республик (The Law on approval of the Fundamentals of land legislation of the USSR and Soviet Republics) (1969) (http://www.consultant.ru/cons/cgi/online.cgi?req=doc\&base=ESU\&n=44592 ) (In Russian)

12. Земельний Кодекс Української PCP (The Land Code of the Ukrainian SSR (1970) (https://zakon.rada.gov.ua/laws/show/2874\%D0\%B0-07\#Text ) (In Ukrainian) 
13. Класифікації видів цільового призначення земель (Classification of the kinds of intended use of lands) 2010 p. 23 липня Наказ Державного комітету України із земельних ресурсів № 548 . ( http://zakon3.rada.gov.ua/laws/show/z1011-10 ) (In Ukrainian)

14. Лихогруд М.Г., Козіков А.В. Вплив законодавчої бази на структуру національних кадастрових систем (Impact of the legislative base on the structure of the national cadastre systems) // Містобудування та територіальне планування, № 10, 2002. С. 64-75. (In Ukrainian)

15. Лихогруд О.М. Удосконалення нормативної грошової оцінки населених пунктів в сучасних умовах (Improvement of the normative monetary evaluation of settlements in the current conditions) // Збалансоване природокористування, № 3, 2015. С. 26-29. (In Ukrainian)

16. Мартин А.Г. (2013) Новий методичний підхід до нормативної грошової оцінки земель несільськогосподарського призначення (A new methodic approach to normative monetary evaluation of nonagricultural lands) // Землеустрій і кадастр, № 2, 2013. С. 37-59. (In Ukrainian)

17. Методика нормативної грошової оцінки земель населених пунктів (Methodology of normative monetary evaluation of the lands of settlements). 1995 p. 23 березня Постанова Кабінету Міністрів України № 213. ( https://zakon.rada.gov.ua/laws/show/213-95-\%D0\%BF\#Text ) (In Ukrainian)

18. Методика нормативної грошової оцінки земель несільськогосподарського призначення (крім земель населених пунктів) (Methodology of normative monetary evaluation of non-agricultural lands (except for the lands of settlements)) 2011 p. 23 листопада Постанова Кабінету Міністрів України № 1278. ( https://zakon.rada.gov.ua/laws/show/1278-2011-\%D0\%BF.\#Text )( In Ukrainian)

19. Методика нормативної грошової оцінки земель сільськогосподарського призначення (Methodology of normative monetary evaluation of agricultural lands). 2016p. 16 листопада Постанова Кабінету Міністрів України № 831.( https://zakon.rada.gov.ua/laws/show/831-2016-\%D0\%BF\#Text ) (In Ukrainian)

20. Палеха Ю. Проблемні питання співвідношення результатів нормативної грошової оцінки територій населених пунктів різних категорій (Problem aspects of correlation of the results of normative monetary evaluation of the territory of settlements of different categories) // Землевпорядний вісник, № 6, 2012. С. 2-7. (http://nbuv.gov.ua/UJRN/Zv_2012_6_2 ) (In Ukrainian)

21. Палеха Ю.М. (2006) Економіко-географічні аспекти формування вартості територій населених пунктів (Economic and geographical aspects of formation of the price of settlement territory), Профi, Київ, 340сc. (In Ukrainian)

22. Палеха Ю.М. (2009) Теорія і практика визначення вартості територій і оцінки земель населених пунктів України: Дис. ... д-ра геогр. наук: 11.00 .02 (Theory and practice of determination of the price of territory and evaluation of the lands of settlements in Ukraine: dissertation of the Doctor of Geograph. Sciences: 11.00.02), Київ,426 с. 426 с. (In Ukrainian)

23. Порядок нормативної грошової оцінки земель населених пунктів (Procedure of normative monetary evaluation of the lands of settlements). 2018 p. 27 березня № 162 of March 27, 2018 Наказ Міністерства аграрної політики та продовольства України $\quad$ від $25.11 .2016 \quad$ № 489 . (https://zakon.rada.gov.ua/laws/show/z0432-18\#n6 ) (In Ukrainian)

24. Порядок нормативної грошової оцінки земель несільськогосподарського призначення (крім земель населених пунктів) (Procedure of normative monetary evaluation of non-agricultural lands (except for the lands of settlements)) 2013 р. 22 серпня Наказ Міністерства аграрної політики і продовольства України № 508. (https://zakon.rada.gov.ua/laws/show/z1573-13\#Text ) (In Ukrainian)

25. Ступень М.Г., Гулько Р.Й., Залуцький І.Р., Микула О.Я. та ін. (2006) Оцінка земель: Навчальний посібник, Новий Світ - 2000, Львів, 308 с. (In Ukrainian)

Information about the author:

Tetiana Susak, PhD student of Lviv National Agrarian University, Ukraine, Lviv region, Zhovkva district, Dubliany, V.Velykoho Str.1a, phone number +380680095427, e-mail: SusakTO@i.ua.

Fields of interest: land cadastre, land evaluation. 